\title{
Hyperinsulinism due to HNF1A deficiency
}

INSERM

\section{Source}

INSERM. (1999). Orphanet: an online rare disease and orphan drug data base.

Hyperinsulinism due to HNF1A deficiency. ORPHA:324575

Hyperinsulinism due to HNF1A deficiency is a form of diazoxide-sensitive diffuse hyperinsulinism (DHI), characterized by transient or persistent hyperinsulinemic hypoglycemia $(\mathrm{HH})$ in infancy that is responsive to diazoxide, evolving in to maturityonset diabetes of the young subtype 1 (MODY-1; see this term) later in life. 